\title{
UJI KONTAMINASI CRO4 CHROMATE (VI) PADA BUAH APEL LOKAL DAN IMPORT
}

\author{
Yuniastuti T., Wahyuni, I. D., dan N. K. Anggraeni \\ Program Studi S1 Kesehatan Lingkungan \\ Stikes Widyagama Husada \\ Email: tyuniastuti@gmail.com
}

\begin{abstract}
ABSTRAK
Kontaminasi logam berat salah satunya Chromium pada makanan dapat berakibat gangguan kesehatan. Tujuan penelitian ini adalah untuk mengetahui bagaimana kandungan $\mathrm{Cr}$ pada buah apel baik lokal maupun import. Penelitian ini merupakan penelitian deskriptif eksploratif dengan menggunakan 2 kelompok sampel, yaitu apel local dan apel import yang diuji kontaminasi $\mathrm{CrO} 4$ Chromate(VI). Sampel penelitian ini diuji dengan menggunakan Food Contamination Test Kit CrO4 Chromate(VI) (Inagenpro) dan data yang diperoleh berdasarkan perubahan warna dari indikator. Hasil pengujian menunjukkan bahwa kulit apel local tidak mengandung $\mathrm{CrO} 4$ Chromate(VI). Tetapi pada kulit buah apel import diketahui mengandung $3 \mathrm{mg} / \mathrm{l} \mathrm{CrO} 4$ Chromate(VI)dan berada diatas ambang batas aman. Ingesti logam berat termasuk Chromate(VI), akan meningkatkan hambatan terhadap benzapiren hidroksilase yang berperan dalam kontrol pertumbuhan sel.
\end{abstract}

Kata Kunci: Kontaminasi CrO4, Chromate (VI), Buah Apel Lokal dan Import

\section{PENDAHULUAN}

Pencemaran logam berat merupakan salah satu permasalahan lingkungan yang dapat mempengaruhi aspek kesehatan di masyarakat, sehingga dikenal sebagai salah satu toksikan penting. Toksikan dapat mempengaruhi berbagai organ, tergantung pada tingkat toksisitas, port of entry, sifat dasar toksin, reseptor yang mengenali toksin, farmakokinetik dan farmakodinamik toksin itu sendiri (Manahan, 2003). Toksin yang berupa logam berat dapat mencemari lingkungan dan mengkontaminasi melalui makanan. Unsur logam berat ini berasal dari pestisida yang dipakai, sisa buangan industri maupun sisa pengolahan pasca panen. Kontaminasi dapat mengakibatkan gangguan kesehatan yang serius (Anies, 2015).

Keracunan logam berat dapat menimbulkan permasalahan kesehatan yaitu gangguan saluran pencernaan (gastrointestinal), alopesia, susah berkonsentrasi hingga terjadinya gangguan mental serta neuropati perifer. Keracunan logam berat pada 
makanan dapat diperburuk dengan adanya kontaminasi kolinesterase (Arisman, 2008).

Secara umum logam berat yang kemungkinan dapat mengkontaminasi makanan adalah timbal, kadmium dan merkuri (Anies, 2015). Tetapi tetap ada kemungkinan terjadinya kontaminasi logam berat lain seperti Arsenic (As), Total Chromium (Cr), Nichel (Ni), Selenium (Se), Zinc (Zn). Copper $(\mathrm{Cu})$ dan Cobalt $(\mathrm{Co})$. Berdasarkan penelitian yang dilakukan di perairan Jambi, telah ditemukan adanya kandungan logam berat pada sedimennya sedikit tercemar Nickel (Ni) dengan konsentrasi 14 $\mathrm{mg} / \mathrm{kg}$ dan Chromium (Cr) dengan konsentrasi $19 \mathrm{mg} / \mathrm{kg}$. Sedangkan logam berat lainnya berada di bawah nilai ambang batas sehingga dinyatakan aman (Susantoro, et al., 2015). Pencemaran di area muara dapat dibawa oleh aliran sungai di daratan. Pada penelitian yang dilakukan di aliran sungai Siak menunjukan kandungan $\mathrm{Pb}, \mathrm{Cr}$, dan Zn pada sedimen sungai lebih tinggi daripada konsentrasi logam berat di perairan. Hal ini menunjukan bahwa peningkatan konsentrasi logam berat di air diikuti dengan peningkatan konsentrasi logam berat di sedimen (Wulan, et al., 2013).

Buah adalah salah satu jenis hasil pertanian yang dikonsumsi oleh sebagian besar masyarakat. Potensi buah di Indonesia cukup besar tetapi kontribusi buah Indonesia terhadap pasar ekspor dunia hanya 0.15\% (FAO, 2007). Hal ini menyebabkan pasaran buah di Indonesia di dominasi oleh buah import seperti apel, jeruk, lemon, anggur, dan lainnya. Keunggulan yang dimiliki oleh buah import adalah memiliki tampilan yang lebih menarik dan seragam baik dalam ukuran maupun tingkat kematangan, selain itu juga memiliki ketersediaan yang relatif kontinu. Tingkat kompetisi yang semakin ketat dengan adanya persaingan harga, dimana buah import memiliki harga yang kompetitif dengan variasi yang cukup besar. Kekurangan dari buah import adalah proses distribusi yang cukup panjang. Perlakuan pasca panen untuk buah yang akan didistribusi jarak jauh meliputi pencucian, degreening, curing, waxing, precooling, penggunaan pestisida dan bahan kimia. Penggunaan bahan kimia dan 
pestisida inilah akan meningkatkan kemungkinan adanya kontaminasi logam berat dan pestisida.

Penelitian yang dilakukan di Perairan Teluk Jakarta pada Bulan November 2010 menunjukkan bahwa kualitas air laut berada dalam kualitifikasi kelas $\mathrm{C}$ atau tercemar sedang. Bahan pencemar yang terdeteksi adalah : $\mathrm{Cu}(<0.005: 15.000-169.500)$; $\mathrm{Pb}$ (0.005-0.011 : 14.000-58.100); Zn (0.005-0.007 : 95.800-333.000); Cd (0.006-0.015: 0.012-0.750); Cr (<0.001 : 45.320-139.180) dalam sedimen dasar laut dalam ppm. Hal ini menunjukkan bahwa ada pencemaran logam berat pada air laut, sehingga berpotensi untuk terakumulasi pada hasil perikanan (Permanawati, 2013). Hal yang sama juga terjadi di Pelabuhan Parepare, dimana terdeteksi kandungan $\mathrm{Pb}$ di perairan sebanyak 0.0380 -0.8240 ppm dan 4.0580 - $8.4590 \mathrm{mg} / \mathrm{kg}$ berat kering ikan merah (Usman, et al., 2014). Sedangkan untuk kondisi air tanah yang banyak dimanfaatkan oleh petani untuk pengairan lahan pertanian kemungkinan juga dalam kondisi yang sama. Pada penelitian yang dilakukan di Sungai Percut Sumatera Utara, menunjukkan hasil adanya kandungan logam berat pada sedimen sungai dengan kadar 2,7 mg/kg dan kualitas air yang ada belum bisa memenuhi persyaratan sebagai air minum (Al Husainy, et al., 2014). Pemanfaatan air sungai oleh petani utk pertanian tradisional juga dapat menjadi sumber kontaminasi logam berat pada buah. Kondisi sungai atau sumber air yang terkontaminasi oleh limbah industri akan meningkatkan kemungkinan terjadinya kontaminasi. Penelitian ini bertujuan untuk mengetahui bagaimana kandungan $\mathrm{Cr}$ pada buah apel baik lokal maupun import.

\section{METODE PENELITIAN}

Pengujian Ekstrak Penelitian ini merupakan penelitian deskriptif eksploratif dengan menggunakan 2 kelompok sampel, yaitu apel local dan apel import yang diuji kontaminasi CrO4 Chromate (VI). Sampel penelitian ini diuji dengan menggunakan Food Contamination Test Kit CrO4 Chromate(VI) (Inagenpro) dan data yang diperoleh berdasarkan perubahan warna dari indikator. Data akan 
dianalisa secara deskriptif dan dibandingkan dengan nilai ambang batas aman logam berat.

\section{HASIL DAN PEMBAHASAN}

3.1 Hasil Pengujian CrO4 Chromate (VI) pada kulit buah apel baik yang local maupun yang import

Pengujian $\mathrm{CrO} 4$ Chromate (VI) pada kulit buah apel baik yang local maupun yang import dilakukan dengan menggunakan Food contamination kit. Hasil pengujian ini akan disajikan dalam table dibawah ini.

Table 1. Hasil Pengujian CrO4 Chromate (VI) pada Kulit Buah Apel

\begin{tabular}{cccc}
\hline No. & Nama Sampel & Hasil Pengujian & $\begin{array}{c}\text { Ambang Batas } \\
\text { Aman }\end{array}$ \\
\hline 1. & Apel local 1 & $0 \mathrm{mg} / \mathrm{l}$ & \\
2 & Apel local 2 & $0 \mathrm{mg} / \mathrm{l}$ & \\
3 & Apel local 3 & $0 \mathrm{mg} / \mathrm{l}$ & $0,05 \mathrm{mg} / \mathrm{l}$ \\
4 & Apel import 1 & $3 \mathrm{mg} / \mathrm{l}$ & \\
5 & Apel import 2 & $3 \mathrm{mg} / \mathrm{l}$ & \\
6 & Apel import 3 & $3 \mathrm{mg} / \mathrm{l}$ & \\
\hline
\end{tabular}

Dari table diatas, diketahui bahwa kulit apel local tidak mengandung $\mathrm{CrO} 4$ Chromate(VI). Tetapi pada kulit buah apel import diketahui mengandung $3 \mathrm{mg} / \mathrm{l}$ CrO4 Chromate(VI)dan berada diatas ambang batas aman.

\subsection{Pembahasan}

Kegiatan industry menghasilkan limbah cair yang sebagian besar dibuang di aliran sungai, sehingga terjadi penurunan kualitas air. Aliran sungai yang memiliki peranan penting dalam kehidupan masyarakat, yaitu sebagai DWTP, MCK, sumber air untuk kegiatan pertanian dan perikanan. Kali Pelayaran yang berada di area industry di Sidoarjo mengalami kenaikan kadar $\mathrm{Cr}$ di air pada kisaran nilai 0,94 1,12 mg/L dan 3 kali lebih tinggi dibandingkan dengan Peraturan Pemerintah No. 82 
Tahun 2001 tentang Management Kualitas Air dan Pengendalian Pencemaran Air yang berada pada nilai $0.05 \mathrm{mg} / \mathrm{L}$ (Kristanto, et al., 2017).

Pencemaran badan air yang dimanfaatkan untuk kegiatan pertanian, merupakan salah satu kemungkinan sumber pencemaran Chromat pada hasil pertanian. Pada hasil penelitian ini, pada buah apel import ditemukan adanya kandungan $\mathrm{CrO} 4$ Chromate(VI)pada ketiga sampelnya dengan jumlah yang berada diatas nilai ambang batas aman, yaitu $3 \mathrm{mg} / \mathrm{l}$. Hal ini kemungkinan disebabkan oleh adanya kontaminasi CrO4 Chromate (VI) pada lahan pertanian, pengolahan paska panen dan proses pengangkutan dari negara asal.

Chromat pada makanan dan masuk ke tubuh melalui ingesti memungkinkan adanya akumulasi toksin di tubuh. Chromat dalam bentuk hexavalen di dalam tubuh dapat menghambat sistem kerja enzim benzapiren hidroksilase yang berperan dalam proses pertumbuhan sel. Apabila terjadi penghambatan pada enzim ini, maka akan menimbulkan hilangnya kontrol pada pertumbuhan sel, sehingga dapat memicu terjadinya keganasan (Wulaningtyas dan Sudarmaji, 2018).

\section{KESIMPULAN}

Dari hasil penelitian ini dapat disimpulkan bahwa ada kandungan $\mathrm{CrO} 4$ Chromate(VI) pada kulit buah apel import yang melebihi ambang batas aman. Hal ini kemungkinan adanya kontaminasi pada saat proses pra distribusi hasil panen.

\section{REFERENSI}

Al Husainy, I., Bakti, D., dan R. Leidonald. 2014. Analisis Kandungan Logam Berat Timbal $(\mathrm{Pb})$ di Air dan Sedimen Aliran Sungai Percut Propinsi Sumatera Utara. USU. Medan

Anies. 2015. Penyakit Berbasis Lingkungan. Sleman : Ar Ruzz Media. 978-602313-016-0.

Arisman. 2008. Keracunan Makanan ; Buku Ajar Ilmu Gizi. Jakarta : EGC,. 978979-448-972-7.

Kristanto, S., Wilujeng, S., Wahyudiarto, D., 2017. Analisis Logam Berat Kromium (Cr) Pada Kali Pelayaran Sebagai Bentuk Upaya Penanggulangan Pencemaran Lingkungan di Wilayah Sidoarjo. Jurnal Biota. Vol. 3 No. 2 Edisi Agustus 
Manahan, SE. 2003. Toxicological Chemistry and Biochemistry. Florida: CRC Press. RA1219.3.M36.2002.

Permanawati. Y., Zuraida. R., dan A. Ibrahim. 2013. Kandungan Logam Berat ( $\mathrm{Cu}, \mathrm{Pb}, \mathrm{Zn}$ dan $\mathrm{Cr}$ ) dalam Air dan Sedimen di Perairan Teluk Jakarta. Jurnal Geologi Kelautan. Vol. 11 No. 1 (April).

Purnama

Susantoro TM, Sunarjanto D, Andayani A. 2015. Distribusi Logam Berat pada Sedimen di Perairan Muara Dan Laut Jambi. Jurnal Kelautan Nasional. April, Vol. 10, 1.

Usman, S., Nafie, N.L, Ramang, M. 2013. Distribusi Kuantitatif Logam Berat Pb dalam Air, Sedimen dan Ikan Merah (Lutjanus erythropus) di Sekitar Perairan Pelabuhan Pare - Pare. Marina Chimica Acta. Vol 14. No. 2 Makassar

Wulan SP, Thamrin, Amin B. 2013. Konsentrasi, Distribusi, dan Korelasi Logam Berat Pb, Cr, dan Zn Pada Air dan Sedimen di Perairan Sungai Siak Sekitar Dermaga PT Indah Kiat Pulp and Paper Perawang. Pekan Baru : Pusat Penelitian Lingkungan Hidup Univeristas Riau.

Wulaningtyas, F.A dan Sudarmaji. 2018. Karakteristik Pekerja Kaitannya Dengan Kandungan Kromium Dalam Urine Pekerja di Industri Kerupuk Rambak $X$ di Magetan. Jurnal Kesehatan Lingkungan. Vol. 10 No. 1 